\title{
The estimation of protein degradability in the rumen from incubation measurements weighted according to rate of passage
}

\author{
By E. R. ØRSKOV AND I. McDONALD \\ The Rowett Research Institute, Bucksburn, Aberdeen AB2 9SB
}

(Received 15 November 1978)

\begin{abstract}
SUMMARY
A method is proposed for estimating the percentage of dietary protein that is degraded by microbial action in the rumen when protein supplement is added to a specified ration. The potential degradability, $p$, is measured by incubating the supplement in artificial-fibre bags in the rumen and is related to incubation time, $t$, by the equation $p=a+b\left(1-e^{-c t}\right)$. The rate constant $k$, measuring the passage of the supplement from the rumen to the abomasum, is obtained in a separate experiment in which the supplement is combined with a chromium marker which renders it completely indigestible. The effective percentage degradation, $p$, of the supplement, allowing for rate of passage, is shown to be $p=a+[b c /(c+k)]\left(1-e^{-(c+k) t}\right)$ by time, $t$, after feeding. As $t$ increases, this tends to the asymptotic value $a+b c /(c+k)$, which therefore provides an estimate of the degradability of the protein supplement under the specified feeding conditions.

The method is illustrated by results obtained with soya-bean meal fed as a supplement to a dried-grass diet for sheep. The incubation measurements showed that $89 \%$ of the soya-bean protein disappeared within $24 \mathrm{~h}$ and indicated that it was all ultimately degradable with this diet.

When the dried grass was given at a restricted level of feeding the allowance for time of retention in the rumen reduced the estimate of final degradability to $71 \%(69 \%$ within $24 \mathrm{~h}$ ). With ad libitum feeding there was a faster rate of passage and the final degradability was estimated to be $66 \%$ (65\% within $24 \mathrm{~h}$ ).
\end{abstract}

\section{INTRODUCTION}

The importance of the extent of protein degradation in the rumen has been fully recognized in recent years and the subject has been reviewed by Ørskov $(1970,1974,1977)$ and Miller (1973). It is central to new systems which have been proposed for the evaluation of protein requirements for ruminants by the Agricultural Research Counoil (Roy et al. 1977). American workers (Burroughs Trenkle \& Vetter, 1974) have proposed a constant value for the extent of degradability. These systems consider the microbial need for rumen-degradable $\mathrm{N}$ and also the host animal's need for amino acids derived either from microbial protein or from undegraded protein from the feed. Since the extent of degradation determines both the degradable part available for the rumen microbes and the undegraded protein which may be available for host animal enzymic digestion, the importance of quantitative estimates of degradability cannot be overemphasized.
There are essentially two methods of obtaining this information, either by measuring the quantity of dietary protein entering the abomasum or by incubating dietary protein in bags in the rumen for fixed durations. The first method involves the difficulty of maintaining surgically prepared animals, requires lengthy series of analyses, and is subject to uncertainty as to the accurate separation of microbial and dietary protein. In our laboratory we have therefore turned to using an artificial-fibre bag technique (Mehrez \& Ørskov, 1977; Ørskov \& Mehrez, 1977). The preference for this method was reinforced by the finding (Mehrez \& Ørskov, 1978) that not only the extent of degradation but also the rate of degradation was extremely important. The latter cannot be derived from the use of sheep with re-entrant cennulae. The incubation technique, however, has been subject to some uncertainty as to the period of incubation which would be most appropriate, this being dependent upon the time that protein is retained in the rumen.

In this paper an attempt has been made to show 
how results from incubation experiments can be combined mathematically with information on retention times obtained using a method for treating fibre with chromium (Uden, Calucci \& Van Soest, 1978).

\section{METHODS AND RESULTS}

Examples of degradation rate measurements have been taken from experiments reported by Ganev, Ørskov \& Smart (1979). The rates of protein disappearance $(p)$, measured when soya-bean meal was incubated in the rumens of sheep receiving a diet of dried grass, are given in Table 1 and show that $p$ increases with incubation time $(t)$ but at a reducing rate. The measurements can be described by an equation of the form:

$$
p=a+b\left(1-e^{-c t}\right)
$$

where $a, b$ and $c$ are constants fitted by an iterative least-squares procedure. The degradation rate, $p$, is measured under conditions preventing the passage of any of the soya-bean particles from the rumen and is therefore an over-estimate of the extent of degradation at any given time under normal conditions when some particles would already have passed to the abomasum.

In order to estimate rate of passage from the rumen we used soya-bean meal treated with sodium dichromate. The method was developed by Uden et al. (1978) and was suggested to us by $\mathrm{Dr}$ Uden. Ganev et al. (1979) showed that the treatment made the protein completely indigestible, that there was no apparent loss of chromium from the protein particles subsequent to treatment, and that the particle-size distribution was not affected. The rate of dilution of chromium oxide in samples of rumen contents taken at different times could therefore provide estimates of the rate of passage of the treated protein from the rumen to the abomasum and of the proportion remaining in the rumen at any given time after feeding.

Sheep fed on the dried-grass diet, either ad libitum or at a daily feeding level of $70 \mathrm{~g}$ air-dry feed per unit metabolic body weight, were given a single administration of treated soya.bean meal particles. Subsequent measurements of chromium oxide concentration in rumen contents plotted on a logarithmic scale showed a linear decrease with time (Fig. 1). The rate of decrease (k), estimated by regression analysis, can be interpreted as the rate constant or fractional rate at which the treated supplement passes from the rumen to the abomasum, if it is assumed that the weight of rumen contents remains approximately constant. That is to say, if $f$ represents the fraction (by weight) of the treated protein which still remains in the rumen at $t$ hours after feeding, then $f=e^{-k t}$. Assuming that the rate of passage is the same for untreated as for treated protein, and since only protein still in the rumen is subject to degradation, $f$ may be used as a correction factor to apply to the instantaneous rate of degradation at time $t$. Where $p$ is as before the percentage disappearance from the rumen bag at time $t$, the corrected rate of disappearance is therefore $f(d p / d t)$. For soya-bean meal free to pass from the rumen, the cumulative percentage protein degradation up to time $t$ can be obtained by integration and is therefore

$$
\begin{aligned}
P_{t} & =\int_{0}^{t} f \frac{d p}{d t} d t \\
& =\int_{0}^{t} e^{-k t} b c e^{-c t} d t \\
& =a+\frac{b c}{c+k}\left(1-e^{-(c+k) t}\right) .
\end{aligned}
$$

As time from feeding increases, the fraction of

\begin{tabular}{|c|c|c|c|c|}
\hline \multirow[b]{3}{*}{$\begin{array}{l}\text { Time from } \\
\text { feeding }(t)\end{array}$} & \multirow{2}{*}{\multicolumn{2}{|c|}{ Protein disappearance $(\%)$}} & \multicolumn{2}{|c|}{ Effective degradation $\mathbf{P}(\%) \dagger$} \\
\hline & & & Restricted & $\mathrm{Ad}$ libitum \\
\hline & $\begin{array}{c}\text { Measured } \\
(p)\end{array}$ & $\begin{array}{l}\text { Fitted } \\
\qquad(\hat{p})^{*}\end{array}$ & $\begin{array}{c}\text { feeding } \\
(k=0.046)\end{array}$ & $\begin{array}{c}\text { feeding } \\
(k=0.060)\end{array}$ \\
\hline 3 & 38 & 37 & 36 & 36 \\
\hline 6 & 51 & 51 & 47 & 46 \\
\hline 9 & 59 & 62 & 55 & 53 \\
\hline 15 & 79 & 77 & 64 & 61 \\
\hline 24 & 89 & 89 & 69 & 65 \\
\hline$\infty$ & & 100 & 71 & 66 \\
\hline
\end{tabular}
protein remaining in the rumen $(f)$ falls to zero, as

Table 1. Measurements of $\%$ protein disappearance $(p)$ from soya-bean meal held in the rumens of sheep for different lengths of time $(t)$

\footnotetext{
* Values calculated from the fitted equation $\hat{p}=a+b\left(1-\theta^{-c t}\right)$ (fitted constants: $a=20 ; b=80 ; c=0.082$ ). $\dagger$ Estimates of $P$, the effective degradation (\%) of soya-bean protein were calculated from the equation $P=a$ $+[b c /(c+k)]\left(1-e^{-(c+k) t}\right)$ for two values of the rate constant $k$ appropriate to the rate of passage of the soya-bean moal when the dried-grass diet was given either ad libitum or at a restricted level.
} 


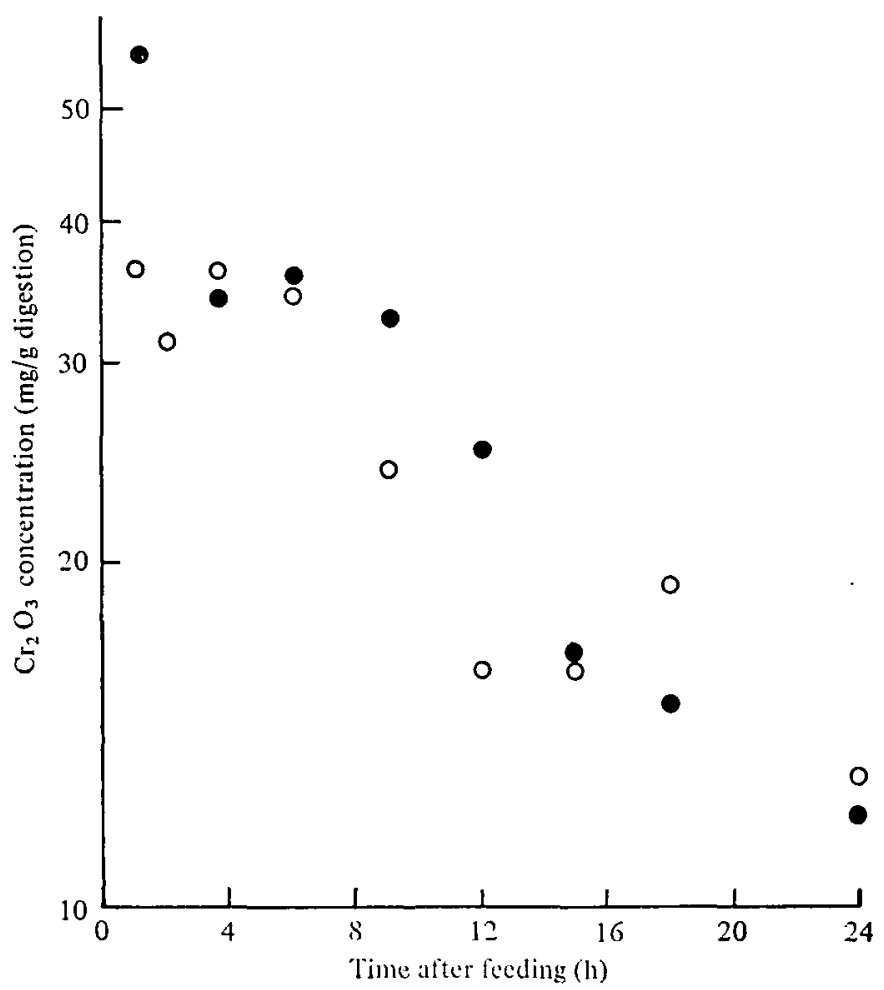

Fig. 1. Effect of time on the dilution of $\mathrm{Cr}_{2} \mathrm{O}_{3}$ in the rumens of sheep receiving dried grass ad libitum (O) or restricted to $70 \mathrm{~g} / \mathrm{kg}^{0.75}(\mathrm{O})$.

does the rate of degradation $(d p / d t)$, and so the percentage protein degradation approaches closer and closer to the final value

$$
P=a+\frac{b c}{c+k} \text {. }
$$

The rumen bag incubation time $t^{*}$ which yields the same degradability as would occur in practice by time $t$, can be calculated by setting

$$
a+b\left(1-e^{-c t *}\right)=a+\frac{b c}{c+k}\left(1-e^{-(c+k) t}\right)
$$

which can be solved to give

$$
t^{*}=\frac{1}{c} \ln \left((c+k) /\left(k+c e^{-(c+k) t}\right) .\right.
$$

The effective degradability, in the limit, is therefore the same as that found by incubation for time

$$
\left.t^{*}=\frac{1}{c} \ln (c+k) / k\right)
$$

but advantage could only be taken of this finding in circumstances where both $c$ and $k$ were known in advance. In general, it will remain necessary to make incubation measurements over a series of times.

An example of the application of these equations is given in Table 1. The rumen bag measurements of protein disappearance yielded estimates of $a=20, b=80$ and $c=0.082$ for the constants in equation (1); good agreement is shown between protein disappearance estimated from this equation and the original measurements. With the restricted feeding level the instantaneous fractional rate of passage of the soya-bean meal from the rumen to the abomasum was $k=0 \cdot 046 / \mathrm{h}$. Estimates of the effective percentage degradation at $3,6,9,15$ and $24 \mathrm{~h}$ after feeding calculated from equation (2) show a progressive divergence from the original uncorrected rumen bag values, the $24 \mathrm{~h}$ value being $69 \%$ as against the uncorrected value of $89 \%$. The final estimate of rumen degradability, from equation (3), was $71 \%$, only slightly greater than the $24 \mathrm{~h}$ value. From equation (4) it may be calculated that rumen incubation over a period of $12.5 \mathrm{~h}$ would have yielded the appropriate value ( $71 \%$ ) for degradability of soya-bean protein under these conditions. When the dried grass was fed ad libitum the rate of passage was faster, $k=0.060$, and the effective degradability was slightly further 
reduced below the incubation estimate. The asymptotic value was $66 \%$, corresponding to a rumen incubation time of $10.5 \mathrm{~h}$.

\section{DISCUSSION}

Provided that our assumptions are justifiable the approach reported here would appear to overcome the main problems encountered in estimating degradability by the artificial-fibre bag technique. As already pointed out the measurements of disappearance from the polyester bags show the proportion that is potentially degradable but make no allowance for the limitation which occurs in practice as particles pass out of the rumen before there has been time for that potential to be realized. The discrepancy will be greatest for those protein sources which are most slowly degraded, and under feeding regimes which promote rapid passage from the rumen to the abomassum.

The equation $p=a+b\left(1-e^{-c t}\right)$ may be considered as providing a purely empirical fit to the incubation data. Alternatively it can be derived theoretically from the assumptions (i) that there exists one protein fraction ( $a ; \%$ total protein) which disappears very rapidly within the period before the earliest removal of a bag from the rumen, and (ii) that a second protein fraction ( $b$; $\%$ total protein) disappears at a constant fractional rate $c$ per unit time. (With some protein supplements there is clearly a third protein fraction which does not disappear over the period of the observations. With other supplements there is evidence of a time lag before the onset of disappearance, which changes the interpretation of parameters $a$ and $b$ but not the form of the equation.) In fitting the equation we have constrained the estimates of $a$ and $b$ to ensure that their total does not exceed $100 \%$. In calculating $P$, the percentage degradation adjusted to allow for rate of passage of partioles from the rumen, we have assumed that the rapidly disappearing fraction is completely degraded in the rumen. This seems a reasonable approximation, for most of the early loss must consist of watersoluble proteins which are known to be degraded very rapidly.

The method by which the incubation data are combined with the estimates of rate of passage is analogous to the mathematical method used by Blaxter, Graham \& Wainman (1956) in order to show how the effective dry matter digestibility of a feed was affected by rate of passage. In their calculations they accumulated the percentage weights of material that had been digested from the residues excreted in successive increments of time

$$
\left(-\int_{0}^{t} p \frac{d f}{d t} d t \text { in our notation }\right)
$$

whereas we accumulate the percentage of material actually degraded in successive increments of time

$$
\left(\int_{0}^{t} f \frac{d p}{d t} d t\right)
$$

Because of the time lag between degradation and passage of the residues our calculation gives a higher value and is more appropriate for finite limits of integration, but the two estimates converge asymptotically as $t$ is increased. These integral solutions, for effective rates of digestibility or degradability respectively, remain correct irrespective of the form of the functions $f$ and $p$. Hence, for example, if it was found that a different equation was required to describe the time course of degradation of some other protein supplement when it was incubated, then it would be relatively simple to find revised expressions to replace equation (3) for estimating effective degradability.

The assumption which is most critical for our calculations is that the rate of passage of the un. treated protein particles is the same as that measured with the chromium-treated particles. Both types would be subject to reductions in particle size caused by chowing and rumination, but as the treated particles were completely indigestible they would not be subject to any reductions in size normally associated with microbial action. However, this is unlikely to invalidate the assumption, for the particle sizes of protein supplements are such that they can enter the abomasum without need for further reduction.

It should be emphasized that the estimates of retention time in the rumen assumed a constant rumen volume. This will no doubt not always be true, particularly with restricted levels of feeding. For the feeding levels used here the dry-matter concentration in the rumen decreased with time of feeding, while the rumen volume appeared not to be significantly changed from estimates of rumen volum $\theta$ before feeding.

The corrected estimate of degradability is obtained by integrating the corrected disappearance rate, $f(d p / d t)$, from time of feeding onwards, but both $f$ and $d p / d t$ decrease with time and so the observations on incubated samples can be terminated at some finite upper time limit. The choice of $24 \mathrm{~h}$ for the upper limit in the example reported here is justified by the finding that the integral of $f(d p / d t)$ beyond $24 \mathrm{~h}$ added very little to the estimate of degradability. If there had been any substantial degradation taking place beyond $24 \mathrm{~h}$ after feeding, the asymptotic estimate (equation 3) would have been less precisely estimated because of the extrapolation beyond the measured values of $p$. Experience with the technique to date suggests that $24 \mathrm{~h}$ maximum incubation will be adequate 


\section{Protein degradability in the rumen}

for most but probably not for all test materials and feeding regimes. If the method was being used on standard types of material it might be possible to estimate the rate constants sufficiently well to use equation (4) to decide upon a single duration of incubation which could provide direct estimates of effective degradability.

The authors thank Sir Kenneth Blaxter for his helpful criticisms of this manuscript.

\section{REFERENCES}

Blaxter, K. L., Graham, N. McC. \& Wainman, F. W. (1956). Some observations on the digestibility of food by sheep and on related problems. British Journal of Nutrition 10, 69-91.

Burrovghs, W., TrenkIe, A. \& Vetter, R. L. (1974). A system of protein evaluation for cattle and sheop involving metabolizable protein (amino acids) and urea fermentation potential of feedstuffs. Veterinary Medicine. Small Animal Clinician 69, 713-722.

Ganev, G., Ørskov, E. R. \& Smart, R. (1979). Effect of type of substrate and retention time on rate and extent of degradation of protein supplements in the rumen. (Submitted.)

Mehrez, A. Z. \& ØRSkov, E. R. (1977). A study of the artificial fibre bag technique for determining the digestibility of feeds in the rumen. Journal of Agri. cullural Science, Cambridge 88, 645-650.

Mirhez, A. Z. \& Ørskov, E. R. (1978). Protein dogradation and optimum urea concentration in cerealbased diets for sheep. British Journal of Nutrition 40, 337-345.

Mrruer, E. L. (1973). Evaluation of foods as sources of nitrogen and amino acids. Proceedings of the Nutrition Society 32, 79-84.

ORskov, E. R. (1970). Nitrogen utilization by the young ruminants. Proceedings of the Fourth Nutrition Conference, Nottingham, pp. 20-35.
Ørskov, E. R. (1974). Factors influencing protein and non-protein nitrogen utilization in young ruminants. In Protein Metabolism and Nutrition (ed. S. Taminga), pp. 457-476. Wageningen, The Netherlands: Contre for Agricultural Publishing.

ØRSkov, E. R. (1977). Dietary protein : energy relationships for growth in young ruminants. In Protein Metabolism and Nutrition (ed. S. Taminga, pp. 110114. Wageningen, The Netherlands: Centre for Agricultural Publishing.

Ørskov, E. R. \& MEHREZ, A. Z. (1977). Estimation of extent of protein degradation from basal foeds in the rumen of sheep. Proceedings of the Nutrition Society 36, $78 \mathrm{~A}$.

RoY, J. H. B., BaLCH, C. C., MmLER, E. L., Ørskov, E. R. \& SмrтH, R. H. (1977). Calculation of the N-requirements for ruminants from nitrogen meta. bolism studies. In Protein Metabolism and Nutrition (ed. S. Taminga, pp. 126-129. Wageningen, The Netherlands: Centre for Agricultural Publishing.

Uden, P., Colucor, P. E. \& VAN Soest, P. J. (1978). Investigation of chromium, cerium and cobalt as markers in digesta rate of passage studies. Journal of the Science of Food and Agriculture. (In the Press.) 